\title{
Belajar Membaca Al-Quran Dengan Metode Qiroati Di KB Mutiara Insani
}

\author{
Hasan \\ IAI Dar Aswaja \\ Rokan Hilir \\ hasanlubis20@gmail.com
}

\section{Abstrak}

Jurnal ini bertujuan untuk memberikan gambaran tentang belajar membaca Al-Qur'an dengan metode Qiroati yang dilaksanakan di KB Mutiara Insani Penelitian ini adalah penelitian deskriptif Kualitatif dengan prosentasi. Adapun hasil penelitian dibagi pada dua kategori yaitu capaian individu dan dan lembaga: Secara individual: 15 orang peserta didik hanya mampu sampai jilid 2 dengan tingkat penguasaan $33 \%$, 8 orang peserta didik KB Mutiara Insani hanya mampu sampai jilid 3 dengan tingkat penguasaan 50\%, 2 Orang peserta didik KB Mutiara Insani mampu sampai jilid 4 dengan tingkat penguasaan 66\%, 6 Orang peserta didik KB Mutiara Insani Mampu sampai jilid 5 dengan tingkat penguasaan 83\%, 10 Orang peserta didik KB Mutiara Insami mampu membaca AlQur'an sampai jilid 6 (sampai Alqur'an) dengan tingkat penguasaan 100\% dengan kategori Sangat Baik. Sedangkan untuk target pencapaian penguasaan tingkat lembaga (KB. Mutiara Insani) 61,59\% dengan kategori Kurang.

\section{Abstract}

This journal aims to provide an overview of learning to read the Qur'an with the Qiroati method carried out at KB Mutiara Insani. This research is a qualitative descriptive study with a percentage. The results of the study were divided into two categories: 
individual and institutional achievements: Individually: 15 students were only able to reach volume 2 with a mastery level of 33\%, 8 KB Mutiara Insani students were only able to volume 3 with a mastery level of 50\%, 2 KB Mutiara Insani learners are able to reach volume 4 with a mastery level of 66\%, 6 KB Mutiara Insani learners are able to volume 5 with a mastery level of $83 \%$, $10 \mathrm{~KB}$ Mutiara Insami learners are able to read the Qur'an until volume 6 (up to the Qur'an) with a level of mastery of $100 \%$ with the category of Very Good. As for the target of achieving mastery at the institutional level (KB. Mutiara Insani) $61.59 \%$ with the category Less.

\section{Kata Kunci: Belajar Al-Qur'an, Metode Qiroati Keywords: Learning Al-Qur'an, Qiroati Method}

\section{A. PENDAHULUAN}

Setiap agama pasti mempunyai kitab suci. Kitab tersebut berfungsi sebagai pertunjuk terhadap pemeluk agamanya. Demikian halnya dengan agama Islam. Agama Islam mempunyai kitab suci yang bernama Al-Qur'an. Alquran berfungsi sebagai pedoman dan panduan bagi setiap muslim dan muslimat. Karena Al-Quran adalah pedoman dan panduan bagi ummat Islam, berarti Alqur'an wajib untuk dipelajari. Mempelajari membaca Al-Qur'an adalah sarana untuk membaca. Membaca adalah sarana untuk dapat memahami makna dan kandungan Alqur'an itu sendiri. Untuk dapat membaca Al-Qur'an tentulah harus melalui proses belajar. Dan belajar merupakan kewajiban bagi seiap muslim dan muslimat.

Dalam belajar membaca Alqur'an hari ini hadir beberapa metode. Di antaranya metode juz Amma Bagdadiyah, Metode Iqra, Metode Ummi, Metode Tabarak dan metode Qiroati. 
1. Pengertian AlQur'an

Al-Qur'an berasal dari bahasa Arab

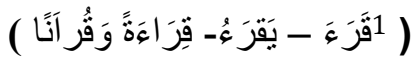

artinya membaca. Sedangkan secara Istilah Al-Qur'an adalah Kalam Allah yang diturunkan kepada Nabi Muhammad Sallallahu 'alaihi wasallam melalui malaikat Jibril, sampai kepada kita secara mutawatir. Ia dimulai dengan surah Al-Fatihah dan diakhiri dengan Surah AnNas, dan dinilai ibadah (berpahala) bagi setiap orang yang membacanya. ${ }^{2}$

2. Hukum Belajar Al-Qur'an

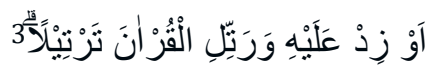

Artinya: atau lebih dari (seperdua) itu, dan bacalah AlQur'an itu dengan perlahan-lahan.

Peraturan Menteri Agama Republic Indonesia No 13 Tahun 2014. Tentang pendidikan keagamaan Islam pada BAB I pasal 1 ayat 11 disebutkan: Pendidikan Al-Qur'an adalah lembaga pendidikan keagamaan Islam yang bertujuan untuk memberikan pengajaran bacaan tulisan, hafalan dan pemahaman Al-Qur'an. Pada bab III Pendidikan Diniyah bagian ke satu umum pasal 27 disebutkan "kurikulum pendidikan keagamaan Islam sebagaimana dimaksud pada pasal 26 pada satuan pendidikan Diniyah formal Ula paling sedikit memuat : a.

1 Ahmad Warson Munawwir, Kamus Munawwir Arab-Indonesia Terlengkap. Pustaka Progressif Surabaya h. 1101

${ }^{2}$ Kadar M. Yusuf, Studi Al-Qur'an. Amzah, Jakarta, 2014 h. 1

3 Al-Qur'an Surat Al-Muzammil, ayat, 4 
al-Qur'an, b. Hadits, c. tauhid, d. Fiqih, e. Akhlaq, f. Tarikh g. dan bahasa Arab.4

$$
\begin{aligned}
& \text { حدثنا حجاج بن منهال حدثنا شعبه قال اخبرني علقمة بن مرثد سمعت سعد بين }
\end{aligned}
$$

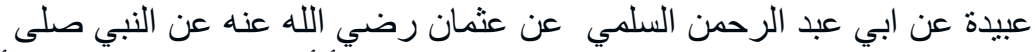

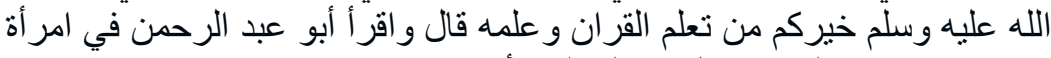

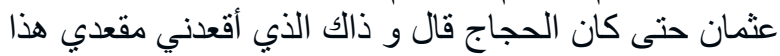

Artinya:Telah menceritakan kepada kami Hajjaj bin Minhal telah menceritakan kepada kami Syu'bah ia berkata, telah mengabarkan kepadaku Alqamah bin Martsad aku mendengar Sa'd bin 'Ubaidah dari Abdurrahman As-Sulami dari Ustman semoga Allah meridhoinya, dari nabi sallahu'alaihi wa sallam, beliau bersabda, sebaik-baik kamu adalah orang yang belajar Al-Qur'an dan mengajarkannya, Abu Abdirrahman membacakan (alqur'an) pada masa Utsman hingga Hajjaj pun berkata dan hal itulah yang menjadikanku duduk di tempat dudukku ini. ${ }^{5}$

Orang yang terbaik adalah orang yang terkumpul dari dua sifat yaitu: orang yang mempelajari Al-Qur'an dan kemudian dia pun mengajarkannya. Ia mempelajari Alqura'an dari gurunya, kemudian ia mengajarkan Al-qur'an kepada orang lain. Mempelajari dan mengajarkannya di sini mencakup mempelajari dan mengajarkan lafazd-lafazd Al-qur'an dan mencakup juga mempelajari dan mengajarkan makna-makna Al-Qur'an.

3. Fadhilah Membaca Al-Qur'an

حدثنا قتيبة بن سعيد ومحمد بن عبيد الغبري جميعا عن ابي عوانة قال ابن عبيد حدثنا

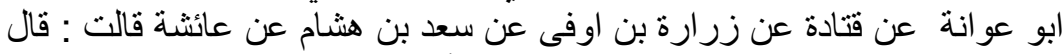

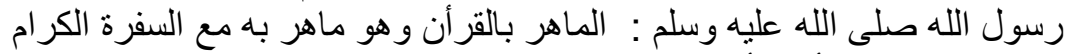

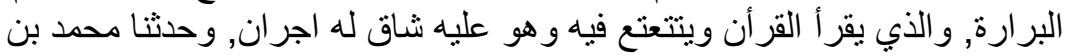

4 Peraturan Menteri Agama Republic Indonesia No 13 Tahun 2014. Tentang pendidikan keagamaan Islam

5 Muhammad bin Ismail, Shahih Bukhar, Daar Ibn Katsir Damaskus 2002 HR. Bukhari No. 4639 


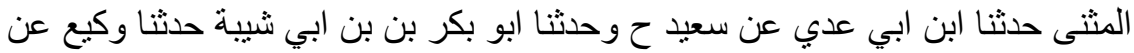

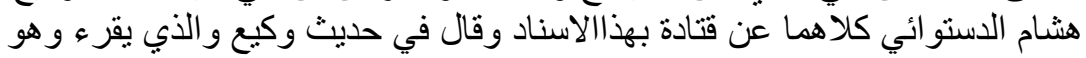

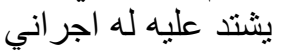

Artinya: Telah menceritakan kepada kami Qutaibah bin Sa'id dan Muhammad bin'Ubaid Al-Gubari semuanya dari Abu 'Awanah Dar Qatadah Daru Zurarah bin Aufadari Sa'd bin Hisyam dari 'Aisyah: dia berkata rasulullah sallahu 'alaihi wasallam bersabda orang-orang mukmim yang membaca Al-Qur'an, dan dia membacanya dengan mahir. maka dia bersama malaikat yang mulia. Dan orang-orang yang membaca Al-Qura'an dengan terbata-bata, dan dia merasa kesulitan, maka dia mendapat dua pahala. Dan dari jalur lain telah mencritakan kepada kami Muhammad bin Mutsanna telah menceritakan kepda kami Abu 'Adi dari Sa'id dan diganti dengan jalur periwayatan lain dan telah menceritakan kepada kami Abu Bakar bin Abi Syaibah telah mencritakan kepada kami telah menceritakan kepada kami Waki' bin Hisyam Ad-Dastawai keduanya dari Qatadah dengan isnad ini. dan ia berkata dalam hadist Waki' dan orang yang membaca Al-Qur'an sedang ia kesulitan dalam membacanya, maka baginya dua pahala. ${ }^{6}$

حدثنا قتيبةحدثنا ابو عو انه عن قتادة عن أنس عن أبي موسى الاشعري قال : قال

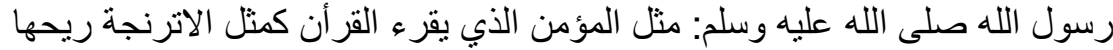

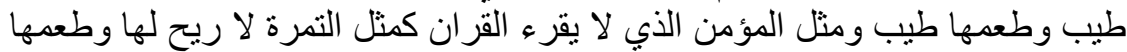

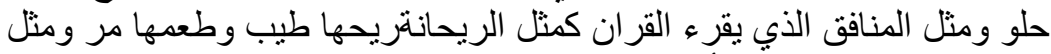
المناقف الذي لا يقرء ألقرأن كمثل الحنظلة ريحها مر وطعدها مر 7 Artinya: Qutaibah menceritakan kepada kami, Abu 'Awanah menceritakan kepada kami dari Qatadah, dari Anas, dari

No.1329

Abul Husain Muslim bin muslim Al-Hajjah, Kitab Shahih Musim

7 Muhammad Nasiruddin Al-Albani, Shahih Sunan Tirmizdi (Seleksi Hadits Shahih dari Kitab Sunan Tirmizdi). Pustaka Azzam Jilid III. No. 2865 
Abu Musa Al-Asy'ary. Ia berkata Rasulullah Sallahu 'Alaihi Wasallam bersabda perempamaan seorang mukmin yang membaca Al-Qur'an adalah seperti buah Al-Urtujah yang aromanya harum dan rasanya pun lezat. Perumpaan seorang mukmin yang tidak membaca Al-Qur'an adalah seperti buah buah kurma yang tidak meiliki aroma namun rasanya manis. Perumpamaan orang munafik yang membaca Al-Qur'an adalah seperti Ar-Raihanah aromanya harum rasanya pahit. Sedangkan perumpamaan orang munafik yang tidak membaca Al-Qur'an adalah seperti Hanzhalah aromanya pahit dan rasanya pun pahit.

\section{B. METODE PENELITIAN}

Jenis Penelitian yang digunakan adalah Penelitian Lapangan (Field Research). dengan pendekatan deskriptif Kualitatif.8 Tempat penelitian di KB Mutiara Insani Kabupaten Kampar pada Tahun 2020. Waktu Penelitian ini dilaksanakan mulai balan Desember 2019 sampai Februari 2020. Teknik pengumpulan data yang digunakan pada penelitian ini adalah Observasi dan dokumentasi. ${ }^{9}$ Teknik Peneliti mengumpulkan Kartu Prestasi Belajar Qiroati Peserta didik. Adapun Teknik analisis data dilakukan dengan cara menyeleksi dan mengelompokkan, kemudian memaparkan atau mendeskripsikan data dan yang terakhir menyimpulkan. ${ }^{10}$ Untuk menentukan tingkat keberhasilan belajar metode Qiroati, digunakan Skala:

Arti tingkat penguasaan:

8 Saifuddin Azwar, Metode Penelitian, Yogyakarta: Pustaka Pelajar, 1998, cet. 1, hal.5.

9 IG. A.K Wardhani, Langkah-Langkah Penelitian Tindakan Kelas, 2.23 Universitas Terbuka, Tangerang Selatan 2014.

${ }^{10}$ Ibid, 2.31 
$90-100 \%$ = baik sekali

$80-89 \%=$ baik

$70-79 \%=$ cukup

$<70 \%=$ kurang $^{11}$

C. PEMBAHASAN DAN HASIL

1. Materi Pokok Mengajar Qiraati Jilid I

a. Materi Mengenal Huruf Hijaiyah Berharkat Fathah

1) Guru langsung membaca huruf hidup A (i) tanpa dieja (jangan dibaca Alif Fathah A).

2) Guru tidak boleh pindah ke huruf hidup (بَ) sebelum huruf hidup A (i) betul-betul dipahami oleh murid.

3) Murid diberi tugas mencari dan menghitung huruf $A$ (i) yang ada di halaman satu.

4) Setelah murid faham ada huruf hidup A (i) baru pindah pada huruf (بَ) dengan metode yang sama seperti di atas.

5) Setelah murid faham pada huruf hidup A (i ) dan (ب) baru murid disuruh baca huruf-huruf yang ada pada lembar latihan sebagaimana terdapat dalam paket qiroati (AA -BB) (َبَ بَ - آ 1 ) dan seterusnya.

6) Teknis mengajar pada halaman 2-30 sama dengan teknis mengajar pada halaman satu.

7) Mulai halaman 31 sampai halaman 44 bacaannya harus disambung sebagaimana tulisannya, dengan cara memperhatikan titik-titik huruf-huruf yang telah dikenal oleh murid. ${ }^{12}$

11 Adi Suryanto Dkk, Evaluasi Pembelajaran di SD, Universitas Terbuka. Cet. Ke 19. Tangerang Selatan, 2016, PDGK4301/MODUL1, 1. .17

12 Suroto Suruji Dkk, Metode Praktis Mengajar Qiroati (Pegangan Guru) Sekpend. TKA. Bata-Bata 


\section{b. Materi Dalam Kotak Bawah}

Guru memperkenalkan huruf hijaiyah sesuai dengan kelompok yang dibaca (Alif, Ba, Ta, Tsa') jangan dipisahpisah dan dibaca sesuaidenganmakharijulhurufnya. ***PERHATIAN***

1. Guru hendaknya memperkenalkan halaman yang akan dibaca sebelum memulai pelajaran.

2. Setelah murid sampai pada halaman berikutnya. Hendaklah halaman sebelunya ditanyakan kembali. (contoh murids ampai pada halaman 5 maka halaman 1sampai 4 ditanyakan kembali).

3. Guru harus memberikan contoh bacaan pada murid walaupun sudah bisa membaca. Apabila murid dapat melafalkan mirip dengan huruf yang diucapkan guru, maka sudah dianggap cukup. (tidak harus persis).

4. Guru hendaknya menekankan pada murid membiasakan belajar membaca.

5. Huruf-huruf yang perlu didemontrasikan dan dibedakan lagi adalah:

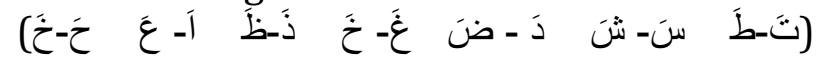

\section{Materi Pokok Mengajar Qiroati Jilid Ii}

\section{a. Materi Pokok}

1) Pada halaman 1sampai 5 merupakan pengenalan harkat kasroh.

2) Pada halaman 6 sampai 10 merupkan pengenalan harkat dhummah.

Agar murid lebih cepat mengenal harkat kasroh dan dhummmah hendaknya guru menggunakan cara sebagai berikut:

a) Guru mencontohkan bunyi harkat kasroh dan dummah secara berulang-ulang dengan metode dilihat dan dibaca (انظر و قال) jangan dieja sebagaimana jilid I. 
b) Guru memberi ontoh suara A (') dengan diikuti muridmembunyikan suara I (I) begitu pula pada harkat dhummah. Agar murid lebih cepat mengenal semua bunyi harkat, maka guru mengajarkan semua nama harkat di kotak bawah pada halaman yang dipelajari, serta menanyakannya berulang-ulang. Kemdian ditunjang dengan syair-syair seperti nyanyian

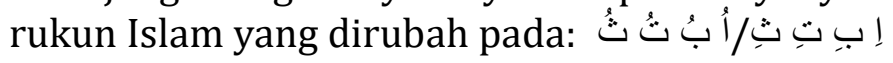

3) Pada halaman 11 sampai 119 pengenalan bunyi tanwin dengan cara guru memberi contoh secara berulang-ulang dan diikuti oleh murid kemdian dibaca sendiri. Untuk lebih mempermudah sebagai penunjangnya adalah lagu-lagu seperti pada bunyi harakat, dengan cara ditanwinkan.

4) Pada halaman 20 sampai 22 pengenalan tulisan TA (ت) yang bermacam-macam dengan suara yang sama tanpa memperhatikan nama dan bentuknya.

5) Pada halaman 23 sampai 32 menerangkan tentang fathah yang dibaca panjang karena diikuti Alif. Dengan cara guru mencontohkan bacaan tersebut $3 \mathrm{x}$ dan diikuti murid secara bersama tanfa waqof (dibaca dengan tahqiq).

6) Pada halaman 33, 34 dan 35 pengenalan fathah panjang/fathah berdiri dengancara membaca seperti harakat fathah yang diikuti Alif, walaupun terdapat bacaan mad wajib hendaklah dibaca mad tobi'e.

7) Pada halaman 36sampai 39 menerangkan tentang harkat kasroh yang dibaca panjang yang diikuti ya sukun. Dengan cara guru mencontohkan bacaan 3x dan diikuti oleh murid secara bersama tanfa waqof (dibaca tahqiq). 
8) Pada halaman 40 sampai 44 pengenalan harkat dhummah yang dibaca njang karena diikuti wawu (و) dengan cara seperti di atas.

\section{b. Materi Dalam Kotak Bawah}

1) Pengenalan macam-macam harakat, angka arab, huruf hijaiyah, bentuk-bentuk penulisan Hamzah dan yang dipisah-pisah.

2) Sebelum murid betul-betul menguasai semua macam harakat, gurutidak boleh melanjutkan pada bacaan panjang.

3) Huruf-huruf yang sering dibaca miring (lemah) adalah huruf berbunyi e atau 0 .

\section{Materi Pokok Mengajar Qiroati Jilid III}

\section{a. Materi Pokok}

1) Pada halaman satu pengenalan Alif yang tidak berfungsi yang ada sesudah Wawu sukun dengan didahului dhummah (dibaca samapanjangnya).

2) Pada halaman 2dan 3 menjelaskan cara membaca (Fathah berdiri). Kasroh panjang (dhummah terbalik) yang diikuti Alif. Kasroh yang iikitu YA dan dhummah yang diikuti WAWU sukun.

3) Pada halaman 4 dan 5 pengenalan LAM sukun, dengan cara ditekan bacaannya, dan jangan sampai memanjangkan bunyi LAM sukun. Untuk lebih mempermudah sebaiknya semua kalimat dibaca $3 \mathrm{x}$ dengantartil dan ditunjang dengan rumus $\mathrm{Al}-$ Qomariyah di bawah ini

$$
\text { الباء بالباء - و الجيم بالجيم ـ الحاء بالحاء - و الخاء بالخاء }
$$

4) Pada halaman 6 dan 9 menerangkan tentan LAM sukun yangdidahului ALIF yang tidak berfunfsi.dibaca seperti LAM sukun yangtidak didahului ALIF. Dengan cara sepertihalaman 4 dan 5 (tidak dibaca panjang). 
5) Pada halam 10 sampai 14 pengenalan huruf sukun. Degan cara menekan huruf sukun tersebut jangan dipantulkan dan dipanjangkan (tawallud) seperti MASJIDUN (مسج) tidak dibaca masejidun / masjidun.

6) Pada halaman 15 sampai 18 menerangkan MIM sukun harus dibaca dengan suara yang jelas dan tidak boleh dipanjangkan (tidak dengung).

7) Pada halaman 19sampai 25 pengenalan perbedaan antara wawu sukun yang didahului harkat dhummah dibaca panjang bersuara U. Apabila didahului harkat Fathah bersuara AU. Jangan sampai dibaca/bersuara AO.

8) Pada halaman 26 dan 27 engenalan LAM ALIF ( $)$ ) bai yang LAM nya sukun dan ALIF nya tathah atau sebaliknya contoh: وَالَُوْ لََادِ

9) Pada halaman 28, 29 dan 30 menerangkan tentang suara LIN. Yakni harkat fathah diikuti WAWUsukun atauYA sukun dan cara bacanya adalah dibaca pendek dan bersuara AU dan AI. Tidak boleh bersuara AO dan AE.

10) Pada halaman 31, 32, dan 34 menjelaskan tentang RA sukun. Di mana cara membacanya sama dengan penjelasan halaman 10, yaitu setiap huruf sukun ditekan bacaanya, jangan terlalu banyak getaran. Seperti MAR ( $\left.{ }^{\circ}\right)$ jangan di baca MARR...R.

11) Pada halaman 35, 36 dan 37 pengenalan perbedaan AIN Sukun dan HAMZAH sukun yang sering kali oleh murid dibaca sama. Dalam hal ini guru dituntut memberi contoh secara berulang-ulang sehingga murid dapat menguasai dengan benar.

12) Pada halaman 38, 39 dan 40 pengenalan car abaca AIn berharkat. Untuk memberikan pelajaran ini seorang guru dituntut lebih sabar dan telaten. Karena 
huruf AIN adalah huruf yang terasa berat diucapkan dan sulit dilafalkan dengan benar oleh murid.

13) Pada halaman 41 menerangkan tentang $F^{\prime}$ sukun. Untuk menghindari kekaburan dengan BA' sukun. Maka guru harus memberikan dengan benar dan jelas. Yaitu $F^{\prime}$ sukun dibaca dengan hembusan angina yang keluar dari mulut, lain halnya dengan $\mathrm{BA}^{\prime}$ sukun (tanpa hembusan).

14) Pada halaman 42 sampai dengan 44 adalah halaman latihan mengenai materi pelajaran sebelumnya.

b. Materi Kotak Bawah

1) Pengenalan angka arab ratusan.

2) Pengenalan فو اتح السور yang dibaca sebagaimana aslinya (tanpa tajwid artinyatidak dipanjangkan ) bacaALIF LAM MIM tidak bolh dibaca Alif Laa...m Mi...m.

3) Pengenalan huruf sukunyang dibaca lengkap dengan sukunnya ('Ain sukun, Hamzah sukun dan seterusnya).

\section{Materi Pokok mengajar Qiroati Jilid IV}

\section{a. Materi Pokok}

1) Pada halaman 1 sampai dengan 4 pengenalan NUN sukun yang dibaca dengung tanpa menjelaskan hukum bacaan ada murid (Ikhfa, idgham dan sebagainya). Guru memberi contoh dengung yang panjang. Untuk memudahkan tanggapan murid harusditunjang dengan materi tambahan rumus di bawah ini:

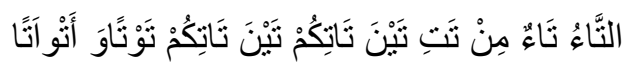

2) Pada halaman 5 dan 6 menerangkan tentang persamaan bunyi NUN mati dan TANWIN. Caranya guru mempraktekkan langsung baik secara lisan maupun tuisan dan diberitahukan pada murid bahwa setiap tanwin dan nun dibaca dengung. 
3) Pada halaman 7, 8 dan 9 menerangkan perbeaan antara MAD TOBIE dan MAD WAJIB dan MAD JAIZ supaya dibaca panjang sesuai ukuran madnya yakni lebih panjang dari mad tobie. Seluruh kalimatnya dibaca 3 x. yang ketiga dibaca waofsesuai kalimatnya.

4) Pada halaman 10 dan 11 pengenalan perbedaan antara bunyi SIN dan SYIN baik yang berharkat maupun yang sukun.

5) Pada halaman 12 sampai dengan halam 15 pengenalan NUN TASYDID dan MIM TASYDID untuk lebih mudah pengennalannya pada murid hendaklah didukung dengan materi tepuk-tepuk dan rumus di bawah ini:

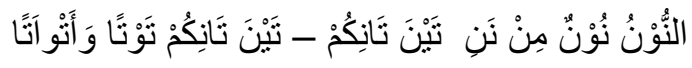

6) Pada halaman 6 sampai dengan halaman 18 pengenalan perbedaan bunyi HA' dan KHA' baik yang berharkat maupun yang sukun, untuk mempermudah kefasihan murid dalam melafalkan dan hendaknya didukungoleh rumus:

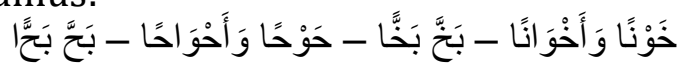

7) Pada halaman 19 sampai halaman 22 pengenalan huruf bertasydid. Setiap huruf bertasydid bacaannya ditekan dan jangan dipanjangkan selain hurug ghunnah.cara untuk memudahkan pemahaman pada murid hendaknya guru memberikan contoh huruf bertasdid dengan ditulis huruf aslinya yakni: dua huruf yang sama yang pertama sukun عَلْنَ - عَلَّ

8) Pada halaman 23 dan halaman dua puluh empat menerangkan huruf ALIF LAM yang tidak befungsi (AL- Syamsiyah) dengan cara huruf alif lamnya tidak dibaca (seolah-olah tidak ada) perlu diperhatikan. Jika berhadapan dengan NUN tetap dibaca dengung. Untuk lebih mudah pengenalannya pada murid sebaiknya ditunjang dengan rumus: 


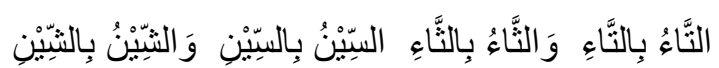

9) Contohkan semua huruf syamsiyah dengan menggunakan rumus di atas. Lihat halaman 23 Qiroti Jilid IV.

10) Pada halaman 25 sampai dengan halaman 29 menerangkan tentaang huruf WAWU yang tidak ada tanda sukunnya baik yangdidahului harkat Fathah atau harkat dhummah. Dalam membacanya WAWU tidak difungsikan.

11) Pada halam 30 dan 31pengenalan MIM SUKUN yang tidak boleh dibaca dengung kecuali MIM SUKUN yang berhadapan dengan MIM, maka harus dibaca dengung. Lihat petunjuk di bawah garis Qiroati Jilid IV halaman 30.

12) Pada halaman 32sampai dengan halaman 35 menerangkan NUN SUKUN /TANWIN bertemu dengan huruf MIM yang dibaca sama dengan MIM SUKUN bertemu MIM. Caranya suara nun sukun dilafalkan dengan suara mim sukun, dan dibaca dengung. Sebagai penunjangnya adalah rumus sebagai berikut:

$$
\text { المِيْمُ مِيْمِ مِنْ مَدِّ مَيْنَ مَامِكُمْ - مَيْنَ مَامِكُمْ مَوْمًا وَأَمْوَ امًا }
$$

13) Pada halaman 36 sampai dengan halaman 40 menerangkan NUN SUKUN atau TANWIN jika berhadapan dengan huruf LAMata RA' TASYDID, maka bunyi huruf nun sukun atau tanwin diganti suara lam dan ra'. Untuk lebih mudah pengenalannya pada murid sebaiknya dengan rumus sebagai berikut:

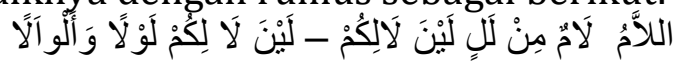

14) Pada halaman 41sampai dengan halaman 44 adalah lembar latihan membaca dengan baik dan benar potongan-potongan ayat yang mengandung pokok pelajaran jilid IV. 
b. Materi dalam Kotak Bawah

1) Pada halaman 3 pengenalan mad lazim harfi musyba' dengan dibaca 3 alif.

2) Pada halaman 2, 4 dan 5 pengenalan macammacam harakat.

3) Pada halaman 6 adalah:

$>$ Pengenalan Mad Tobi'e harfi dibaca satu alif.

$>$ Mad Lazim Harfi Musyba'

4) Pada halaman 8 14, 20, 22, 24, 27, 28, 31, 35, 41, 42 dan 43 adalah pengenalan فواتح السور harus dibaca dengan semestinya (dengan bertajwid).

5) Pada halaman 21, 26 dan 37 adalah latihan membaca menebak halaman dari puluhan hingga ratusan.

6) Pada halaman 33 dan 34 adalah pengenalan huruf Izdhar, Idgham Bigunnah, Idgham Bila Gunnah dan Qolqolah.

\section{Materi Pokok Mengajar Qiroati Jilid V}

\section{a. Materi Pokok}

1) Pada halaman 1, 2, 3, 4 dan 5 menerangkan NUN SUKUN/TANWIN apabila bertemu WAWU da YA harus dibaca dengung, lihat etunjuk di kotak bawah halaman 1 dan 4 Qiroati jilid 5.

2) Pengenalan cara membaca waqaf yaitu pada halaman 3, 6, 11 dan 23 dengancara sebagai berikut:

a) Bacalah $3 \times$ dengan cara di waqof semua secara klasikal (bersama).

b) Guru membaca dengan semestinya (tahqiq) lalu murid disuruh membaca dengan waqof. Lihatpetunjuk kotak bahwa qiroati jilid $\mathrm{V}$ halaman 6, 11 dan 23.

3) Pada halam 7, 20 dan 26 murid ditekankan untuk melafalkan huruf $\dot{\varepsilon}-\dot{-}-$ ॰ yang berharkat 
dan sukun dengan makhroj yang baikdan benar. Untuk lebih dipahami oleh murid hendaknya ditunjang dengan rumus: هَوْهًا وَاََهوَاهًا dengan dibaca $4 \mathrm{x}$.

4) Pada halaman 8, 9 dan 10 pengenalan perbedaan , لفظ الجلاله apabila didahului harkat kasroh dibaca tipis. Bila didahului harkat fathah dan dhummah maka dibaca tebal.

5) Pada halaman 12 dan 13 menerangkan NUN MATI atau TANWIN bertemu dengan huruf BA' dibaca IQLAB (suara Nun Sukun atau Tanwin dilafalkan dengan suara MIM Sukun) dan dibaca dengung.

6) Pada halaman 14 dan 15menjelaskan tentang MIM SUKUN bertemu dengan BA' (اخفاء) dengan dibaca dengung seperti MIM SUKUN bertemu MIM (selain MIM dan BA' tidak boleh dibaca dengung) bacalah $3 \times$ yang ketiga di waqof.

7) Pada halaman 16, 19, 24, 25, 28 dan 33 yaitu pengenalan QOLQOLAH untuk lebih dipahami oleh murid hendaknya ditunjang dengan rumus Qolqolah sebagai berikut:

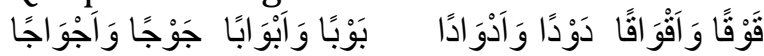

8) Pada halaman 34 dan 35 pengenalan NUN kecil di ataskalimat sebagai tanda IDZHAR

9) Pada halaman 38 pengenalan bacaan mad lazim musyaqqal Kalimi yang harus dibaca tiga alif (6 harkat).

10) Pada halaman 39samai dengan halam 44 adalah halaman latihan guru tinggal mengoreksi dan membetulkan apabila ada kesalahan pada murid dalam membaaca. 


\section{Materi Pokok Mengajar Qiroati Jilid VI}

\section{a. Materi Pokok}

1) Pokok bahasan dari halaman 1 sampai dengan halaman 21menjelaskan tentang hukum bacaan Izdhar Halqi yaitu apabila nun Sukun/Tanwin bertemu dengan salah satu huruf (أ- ه tidak boleh dibaca dengung. Sebaiknya guru menerangkan pokok bahasan secara klasikal dan memberi tugas pada murid untuk menunjukkan bacaan-bacaan yang tidak boleh dibaca dengung (Izdhar Halqi).

2) Pada halaman 22 adalah pengenalan ILLA (Iِ) guru menjelaskan bahwasetiapada tulisan bacaan sebaiknya dibaca washal (diteruskan) dan setiap ada tulisan waqaf.

3) Pada halaman 23 dan seterusnya adalah lembarlatihan dari pelajaran-pelajaran sebelumnya dan merupakan pengenalan materi baru yang perlu dijelaskan oleh guru seperti:

a) Pengenalan tanda waqof dan washal.

b) Pada halaman 25 pengenalan waqof MUA'NAQOH (tanda bertitik tiga di dua tempat) guru menjelaskan cara mewaqof, yaitu dengan berhenti disalah satu tanda tersebut tidak boleh diwashal semua).

c) Pada halaman 27 pengenalan NUN IWADH (nun kecil) guru menganjurkan kalau ada nun kecil sebaiknya diwashal (diteruskan) dan nun diberi harkatkasroh. Kalau terpaksa diwaqof maka nun tidak boleh dibaca guru memberikan contoh yang pertama di waqof dan yang kedua tidak diwaqof.

d) Pada halaman 31 dan selanjutnya yaitu penerapan فواتح السور dan sampai pada halaman 
ini guru dibutuhkan kewaspadaan untuk memperbaiki kelemahan-kelemahan yang terdapat pada bacaan murid sesuaidengan materi yang diajarkan. Perhatikan pada bacaan:

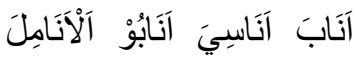

Hati-hati cara membacanya, ini bukan yang dibaca pendek.

7. Hasil Target Capaian Belajar Alqur'an Metode Qiroati Peserta Didik Kb Mutiara Insani Tahun Pelajaran 2019-2020

a. 15 orang peserta didik hanya mampu sampai jilid 2, Dengan tingkat penguasaan $33 \%$ termasuk Kategori Kurang.

b. 8 orang peserta didik KB Mutiara Insani hanya mampu sampai jilid 3, Dengan tingkat penguasaan 50\% termasuk kategori Kurang.

c. 2 Orang peserta didik KB Mutiara Insani mampu sampai jilid 4, dengan tingkat penguasaan 66\% termasuk kategori Kurang.

d. 6 Orang peserta didik KB Mutiara Insani Mampu sampai jilid, dengan tingkat penguasaan 83\% termasuk kategori Baik.

e. 10 Orang peserta didik KB Mutiara Insami mampu membaca Al-Qur'an sampai jilid 6 (sampai Alqur'an, dengan tingkat penguasaan $100 \%$ dengan kategori Sangat Baik.

Sedangkan untuk target pencapaian penguasaan tingkat KB. Mutiara Insani 61,59\% dengan kategori Kurang. 
J-Al-Mutharahah : Vol. 17 No. 1 Januari-Juni 2020

\section{KESIMPULAN}

Berdasarkan hasil penelitian peneliti menyimpulkan: Target pencapaian penguasaan tingkat KB. Mutiara Insani 61,59\% dengan kategori Kurang. Faktor-faktor yang mempengaruhi kekurangan pencaian target, kurang mandirinya sebagian siswa dalam belajar. termasuk sebagian anak tidak mau diajak belajar mengaji.

\section{REFERENSI}

Alquranul Karim, Departemen Agama Republik Inonesia, Bandung: Penerbit Diponegoro, 2007

Abul Husain Muslim bin Muslim Al-Hajjah, Kitab Shahih Musim

Adi Suryanto Dkk, Evaluasi Pembelajaran di SD, Universitas Terbuka. Cet. Ke 19. Tangerang Selatan, 2016

AW. Munawwir, Kamus Al-Munawwir, Arab Indonesia Terlengkap, Surabaya: Pustaka Progressif,1997

IG. A.K Wardhani, Langkah-Langkah Penelitian Tindakan Kelas, 2.23 Universitas Terbuka, Tangerang Selatan 2014.

Kadar M. Yusuf, Studi Al-Qur'an. Amzah, Jakarta, 2014

Mahyuddin Abi Zakariya bin Syarif Annawawi, Riyadus Shalihin, Surabaya.

Muhammad bin Ismail, Shahih Bukhari, Penerbit Daar Ibn Katsir Damaskus 2002

Muhammad Nasiruddin Al-Albani, Shahih Sunan Tirmizdi (Seleksi Hadits Shahih dari Kitab Sunan Tirmizdi). Pustaka Azzam Jilid III.

Peraturan Menteri Agama Republic Indonesia No 13 Tahun 2014, Tentang pendidikan keagamaan Islam

Saifuddin Azwar, Metode Penelitian, Yogyakarta: Pustaka Pelajar, 1998, cet. 1

Suroto Suruji Dkk, Metode Praktis Mengajar Qiroati (Pegangan Guru) Sekpend. TKA. Bata-Bata

Laporan Dapodik KB Mutiara Insani 12 November 2019 